\title{
Evaluasi Penggunaan Antiretroviral (ARV) Berdasarkan Indikator CD4 Pada Pasien HIV di RSPI Prof. Dr. Sulianti Saroso
}

\author{
Evaluation of The Use Of Antiretroviral (ARV) Based On The CD4 Indicator In HIV \\ Patients Of Rspi Prof. Dr. Sulianti Saroso
}

\author{
Dina Mungki Febriani ${ }^{1}$, Stefanus Lukas ${ }^{1}$, Farida Murtiani ${ }^{2}$ \\ ${ }^{1}$ Fakultas Farmasi, Universitas 17 Agustus 1945 Jakarta, Jakarta Utara, Indonesia, 14350 \\ ${ }^{2}$ RSPI Prof. Dr. Sulianti Saroso, Kementerian Kesehatan Republik Indonesia
}

\author{
Korespondensi : \\ Dina Mungki Febriani \\ E-mail : dinamungki@gmail.com
}

\begin{abstract}
Abstrak
Latar belakang: Kasus Human Immunodeficiency Virus (HIV) di Indonesia bahkan di dunia semakin meningkat setiap tahunnya. Obat Antiretriviral (ARV) merupakan pengobatan untuk kasus HIV yang dapat meningkatkan kualitas hidup ODHA walau tidak dapat menyembuhkan. Pemeriksaan CD4 merupakan salah satu indikatorpemantauan pasien untuk melihat keberhasilan penggunaan ARV. Tujuan dari penelitian ini adalah melakukan evaluasi pengobatan sebelum dan sesudah penggunaan ARV berdasarkan indikator CD4 pada pasien RS Prof. Dr. Sulianti Saroso di Jakarta Utara. Metode: desain penelitian cross sectional. Pengumpulan data dilakukan secara non probability sampling dengan teknik quota sampling sehingga diperoleh 42 pasien HIV yang berasal dari data rekam medis pasien. Hasil: analisa sosiodemografi sebagian besar usia $26-45$ tahun $73,8 \%$, jenis kelamin laki-laki $92,9 \%$, pendidikan sarjana $69 \%$, sudah bekerja $88,1 \%$ serta sudah menikah $76,2 \%$. Berdasarkan kepatuhan dalam pengobatan diperoleh $78,6 \%$ patuh. Kombinasi obat yang paling banyak digunakan adalah TDF(300)+3TC(300)+EFV(600) dalam bentuk FDC (fixed-dose combination). Hasil Uji Wilcoxon menunjukan adanya perbedaan bermakna antara CD4 awal dengan CD4 akhir dengan $p$ value $0,000(p<0,05)$. Uji statistik dengan chi square didapatkan status pernikahan, kepatuhan, status pekerjaan dan status pendidikan menunjukan ada hubungan yang signifikan dengan perubahan CD4 (Pvalue $<0,05$ ) sedangkan usia, jenis kelamin, dan kombinasi obat tidak signifikan (Pvalue $>0,05)$. Kesimpulan: ARV efektif menaikkan CD4 pada pasien HIV.
\end{abstract}

Kata kunci: CD4, ARV, HIV/AIDS, Kepatuhan pengobatan ARV.

\begin{abstract}
Background: The number of Human Immunodeficiency Virus (HIV) cases in Indonesia and even worldwide keeps increasing every year. The Antiretriviral (ARV) drug is a form of treatment of HIV that can improve the quality of life of people living with HIVIAIDS (PLWH) even though it cannot cure them of it. A CD4 test result is one of the indicators used in the monitoring of patients to determine the success of ARV use. The aim of this study is to conduct an evaluation of treatment before and after use of ARV based on the CD4 indicator in the patients of RS Prof. Dr. Sulianti Saroso in North Jakarta. Methods: This is a cross sectional study. The data were collected using the non-probability sampling method, namely the quota sampling technique, by which 42 HIV patients were sampled and the data were taken from the patients' medical records. Results: of a sociodemographic analysis show that the majority of the patients are of 26-45 years of age (73.8\%), male (92.9\%), university graduates (69\%), employed (88.1\%), and married $(76.2 \%)$. In terms of their compliance with treatment, $78.6 \%$ were found to be compliant. The most commonly used drug combination is TDF(300)+3TC(300)+EFV(600) in the form of FDC (fixed-dose combination). The results of the Wilcoxon test show a significant difference between the initial CD4 and the final CD4 with the $p$ value of $0.000(p<0.05)$. Based on the chi-square statistical test, it was found that marital status, compliance, employment status, and education level show a significant relation (Pvalue of $<0.05$ ) to the change in the CD4 counts. While age, sex, and drug combination show a no significant (Pvalue of $>0.05$ ). Conclusion: ARV is effective for increasing CD4 cell counts in HIV patients.
\end{abstract}

Keywords : ARV, CD4, HIV/AIDS, Adherence of ARV treatment. 
Pendahuluan

Human Immunodeficiency Virus (HIV) adalah sejenis virus yang menyerang/menginfeksi sel darah putih yang menyebabkan turunnya kekebalan tubuh manusia. Dalam tubuh pasien yang terinfeksi HIV, virus akan bereplikasi secara cepat, dan viral load meningkat tajam. Oleh karena itu, banyak sel CD4 Cluster of Differentiantion (CD4) dihancurkan, dan jumlah sel CD4 turun drastis. Acquired Immunodeficiency Syndrome (AIDS) adalah sekumpulan gejala penyakit yang timbul karena turunnya kekebalan tubuh yang disebabkan infeksi oleh HIV. Akibat menurunnya kekebalan tubuh maka orang tersebut sangat mudah terkena berbagai penyakit infeksi (infeksi oportunistik) yang sering berakibat fatal dan akan berlanjut sampai tahap AIDS. ${ }^{(1)}$

Dilihat dari laporan perkembangan HIV/AIDS triwulan IV tahun 2018, DKI Jakarta merupakan provinsi yang menepati posisi kedua dari sepuluh provinsi yang melaporkan jumlah HIV terbanyak Oktober-Desember 2018 dengan jumlah kasus HIV sebesar 1.802 orang dan kasus AIDS DKI Jakarta menepati posisi keempat dengan jumlah 148 orang. ${ }^{(2)}$ HIV/AIDS semakin nyata menjadi masalah kesehatan utama di seluruh dunia.United Nations Programme on HIVIAIDS (UNAIDS) menyatakan pada tahun 2018 sebanyak 37,9 juta orang di dunia yang terinfeksi HIV dan 770.000 orang meninggal karena AIDS. ${ }^{(3)}$

Penggunaan obat Antiretroviral (ARV) sejak 1996 digunakan dalam pengobatan HIV/AIDS di seluruh dunia. Meskipun belum mampu menyembuhkan HIV/AIDS secara menyeluruh namun terapi ARV menurunkan angka kematian dan kesakitan, meningkatkan kualitas hidup ODHA, dan meningkatkan harapan masyarakat, sehingga pada saat ini HIV/AIDS telah diterima sebagai penyakit yang dapat dikendalikan dan tidak lagi dianggap sebagai penyakit yang menakutkan. ${ }^{(4)}$

Pemeriksaan CD4 merupakan salah satu indikator yang penting untuk menilai keberhasilan penggunaan obat ARV pada pasien HIV/AIDS dan untuk mencegah kemungkinan terjadinya 10 yang disebabkan karena turunnya imunitas dalam tubuh. Diperlukan pemantauan CD4 setiap 6 bulan untuk melihat keberhasilan ARV. Keberhasilan ARV didapatkan jika CD4 mengalami kenaikan sesudah pemberian ARV antara $50-100 \mathrm{sel} / \mathrm{mm}^{3} /$ tahun dengan jumlah CD4 normal yaitu $410 \mathrm{sel} / \mathrm{mm}$ $1590 \mathrm{sel} / \mathrm{mm}^{(5)}$

Hal ini yang mendasari peneliti untuk melakukan penelitian lebih lanjut di RSPI Prof.Dr. Sulianti Saoro Jakarta 
Utara yang merupakan RS rujukan untuk pasien HIV/AIDS di Jakarta Utara untuk melakukan evaluasi penggunaan antiretroviral (ARV) berdasarkan indikator CD4 pada pasien HIV RS Prof. Dr. Sulianti Saroso di Jakarta Utara selama 1 tahun pertama pengobatan ARV.

\section{Metode}

Penelitian ini menggunakan rancangan penelitian bersifat observasional analitik dengan desain penelitian cross sectional dan pendekatan metode retrospektif. Populasi dalam penelitian ini adalah semua pasien positif HIV yang menjalan terapi obat Antiretroveral (ARV) dalam 1 tahun pertama pengobatan di RSPI Prof. Dr. Sulianti Saroso Jakarta pada Periode Januari 2017-Desember 2018 sebanyak 272 responden. Dari perhitungan rumus Lameshow dengan presisi $10 \%$ dan sesuai dengan kriteria inklus yaitu berusia 18-56 tahun, mempunyai data CD4 awal dan akhir sesudah pengobatan serta sesuai dengan kriteria ekluse yaitu data tidak lengkap, meninggal dalam 1 tahun pertama pengobatan, mempunyai penyakit lain selain HIV, ibu hamil dan pasien yang melanjutkan pengobatan ARV di daerah tertentu, diperoleh sampel sebanyak 42 responden yang diambil dengan teknik quota sampling.Sosiodemografi, kepatuhan, jumlah CD4 awal dan CD4 akhir pasien dilihat dari data sekunder yaitu rekam medik pasien yang dimasukan dalam lembar observasi. Analisa data dalam penelitian ini meliputi univariate dan bivariate dengan uji wilcoxon dan uji chisquare. Penelitian ini telah mendapatkan keterangan lolos kaji etik dari Komite Etik Rumah Sakit Penyakit Infeksi Prof. Dr. Sulianti Saroso Jakarta Nomor : 68/XXXVIII.10/XII/2018.

\section{Hasil}

Pasien HIV di RS. Prof. Dr. Sulianti Saroso berdasarkan karakteristik demografi sebagian besar berusia 2645 tahun yaitu 31 (73,8\%), berjenis kelamin laki-laki yaitu 39 orang (92,9\%) berpendidikan sarjana yaitu 29 (69\%) berpendidikan sarjanaberstatus sudah bekerja yaitu 37 (88,1\%), status pernikahan sudah menikah yaitu 32 orang (76,2\%). Berdasarkan kepatuhan penggunaan obat ARV sebagian responden 33 orang $(78,6 \%)$ patuh dalam penggunaan obat ARV, serta tidak adanya responden yang terkena infeksi oportunistik (Table 1). 
Tabel 1. Karakteristik Pasien HIV di RS. Prof. Dr. Sulianti Saroso $(n=42)$

\begin{tabular}{lcc}
\hline Variable & $\mathbf{n}$ & $\%$ \\
\hline Umur & & \\
18-25 Tahun & 8 & 19 \\
26-45 Tahun & 31 & 73.8 \\
46-56 Tahun & 3 & 7.1 \\
\hline Jenis Kelamin & & \\
Perempuan & 3 & 7.1 \\
laki-laki & 39 & 92.9 \\
\hline Pendidikan & & \\
SD & 1 & 2.4 \\
SMP & 3 & 7.1 \\
SMA & 9 & 21.4 \\
Sarjana & 29 & 69 \\
\hline Pekerjaan & & \\
tidak bekerja & 5 & 11.9 \\
Kerja & 37 & 88.1 \\
\hline Pernikahan & & \\
Belum menikah & 10 & 23.8 \\
Menikah & 32 & 76.2 \\
\hline Kepatuhan & & \\
Tidak Patuh & 9 & 21.4 \\
Patuh & 33 & 78.6 \\
\hline Infeksi Oportunistik & & \\
Ada & 0 & 0 \\
Tidak Ada & 42 & 100 \\
\hline
\end{tabular}

Pasien HIV di RS Prof. Dr. Sulianti Saroso lebih banyak menggunakan kombinasi obat $\operatorname{TDF}(300)+3 \operatorname{TC}(300)+$ EFV(600) dalam bentuk FDC dengan jumlah 29 orang (69\%) (Tabel 2). Kombinasi obat ARV yang mengalami kenaikan/perubahan CD4 paling tinggi adalah kombinasi TDF(300)+3TC(300)+ EFV(600) dengan kenaikan jumlah CD4 sebanyak $129 \mathrm{sel} / \mathrm{mm}^{3}$, kombinasi ini juga merupakan kombinasi yang paling banyak digunakan (Grafik 1).

Rata-rata CD4 awal dari 42 responden adalah 253.57 dan CD4 akhir 374.24. Hasil uji Wilcoxon didapatkan pvalue $0,000(p<0,05)$ artinya terdapat perbedaan bermakna antara CD4 sebelum dan sesudah penggobatan ARV (Tabel 3).



Grafik 1. Rata-rata Kenaikan CD4 tiap Kombinasi Obat ARV 
Tabel 2. Distribusi Kombinasi Obat pada Pasien HIV di RS. Prof. Dr. Sulianti Saroso $(n=42)$

\begin{tabular}{ccc}
\hline Kombinasi Obat & $\mathbf{n}$ & $\%$ \\
\hline ZDV(300)+3TC(150)+NVP(200) & 5 & 11,9 \\
\hline ZDV(100)+3TC(150)+EFV(200) & 1 & 2,4 \\
\hline $\operatorname{TDF}(300)+3 T C(300)+E F V(600)$ & 29 & 69 \\
\hline $\operatorname{TDF}(300)+3 T C(150)+E F V(600)$ & 4 & 9,5 \\
\hline $\mathrm{d} 4 \mathrm{~T}(30)+3 T C(150)+\mathrm{EFV}(200)$ & 2 & 4,8 \\
\hline $\operatorname{TDF}(300)+3 T C(150)+\mathrm{NVP}(200)$ & 1 & 2,4 \\
\hline Total & 42 & 100
\end{tabular}

Tabel 3. Perbedaan CD4 Sebelum dan Sesudah Pengobatan ARV pada Pasien HIV di RS. Prof. Dr. Sulianti Saroso $(n=42)$

\begin{tabular}{|c|c|c|c|c|c|c|}
\hline CD4 & Mean & $\begin{array}{c}\text { Negative } \\
\text { rank }\end{array}$ & $\begin{array}{l}\text { Positive } \\
\text { rank }\end{array}$ & Ties & Z hitung & Pvalue $^{\star}$ \\
\hline Awal & 253,57 & \multirow{2}{*}{7} & \multirow{2}{*}{34} & \multirow[t]{2}{*}{1} & \multirow{2}{*}{$-4,289$} & \multirow{2}{*}{0,000} \\
\hline Akhir & 374,24 & & & & & \\
\hline
\end{tabular}

${ }^{*}$ Uji Wilcoxon

Variabel yang mempunyai hubungan bermakna dengan CD4 adalah status pernikahan, kepatuhan, pekerjaan dan pendidikan yang ditandai dengan pvalue $<0,05$ (Tabel 4).

Tabel 4. Hubungan variabel Karakteristik dengan Kenaikan CD4 Pada Pasien HIV di RS. Prof. Dr. Sulianti Saroso $(n=42)$

\begin{tabular}{cc}
\hline Variabel & Pvalue $^{\star}$ \\
\hline Usia & 0,940 \\
\hline Jenis Kelamin & 0,550 \\
\hline Status pernikahan & 0,012 \\
\hline Kepatuhan & 0,000 \\
\hline Status Pekerjaan & 0,050 \\
\hline Status Pendidikan & 0,000 \\
\hline Kombinasi Obat & 0,072
\end{tabular}

*Uji Chi-Square

\section{Pembahasan}

Pada penelitian ini menunjukan bahwa terdapat perbedaan bermakna antara yang sudah menikah dengan yang belum menikah terhadap CD4 sesudah pengobatan. Hal tersebut karena adanya dukungan sosial terutama dukungan yang paling akrab atau kualitas pernikahan yang menjadikan semangat bagi pasien dalam penggunaan obat ARV.

Pasien yang sudah menikah akan mempunyai kedekatan emosional satu sama lain, mereka akan sering bertukar informasi atau saling memberikan motivasi dan mencari solusi dalam menyelesaikan masalah dalam kehidupan seperti masalah kesehatan. 
Dukungan keluarga dapat berupa mengingatkan minum obat, mengingat kepatuhan merupakan faktor penting dalam keberhasilan terapi ARV, mengantarkan ke klinik maupun dukungan berupa finansial. ${ }^{(6)}$ Pengobatan rutin merupakan salah satu cara dalam menaikan imunitas atau meghambat virus HIV. ${ }^{(7)}$ Dengan adanya dukungan membuat seseorang mendapatkan motivasi, penelitian lain oleh Sitepu tahun 2012, menjelaskan bahwa terdapat pengaruh antara motivasi dengan pemanfaatan klinik HIV. Motivasi merupakan faktor yang paling dominan mempengaruhi pemanfaatan pelayanan VCT dikarenakan motivasi seringkali diikuti dengan tindakan. Ketika motivasi seseorang rendah maka seseorang tersebut akan lebih diam, dan ketika motivasi seseorang tinggi maka seseorang tersebut akan lebih bertindak. ${ }^{(8)}$

Kepatuhan adalah faktor penting dalam keberhasilan terapi ARV. Dalam penelitian ini menunjukan bahwa terdapat perbedaan bermakna antara pasien yang patuh dengan tidak patuh terhadap CD4 sesudah pengobatan. Kegagalan terapi ARV sering diakibatkan oleh ketidakpatuhan pasien mengkonsumsi obat ARV, kepatuhan tersebut merupakan kesadaran pasien itu sendiri bukan hanya karena mematuhi perintah dokter saja dan untuk mencapai keberhasilan terapi ARV setidaknya 95\% dari semua dosis tidak boleh terlupakan. ${ }^{(5)}$

Nilai kepatuhan dalam penelitian ini dinilai pada saat pasien mengambil obat dibulan berikutnya dengan minghitung dari jumlah sisa obat pasien yang harus diminum dibagi dengan jumlah obat yang didapat dalam sebulan dan dikalikan seratus, jika presentase yang didapat $>95 \%$ artinya $<3$ dosis obat lupa diminum dalam 30 hari, $80-95 \%$ artinya 3-12 dosis obat lupa diminum dalam 30 hari, dan jika $<80 \%$ artinya $>12$ dosis lupa diminum dalam 30 hari.

Pasien yang masuk dalam kelompok tidak patuh bisa dikarenakan beberapa faktor, seperti terjadinya efek samping dalam penggunaan yang menyebabkan pasien tidak rutin dalam mengkonsumsi obat ARV, bisa juga dikarenakan tidak adanya kesadaran pasien HIV untuk sembuh atau kurangnya perhatian orang sekitar dalam memberikan motivasi kepada pasien selama pengobatan. Hal tersebut dibenarkan dalam penelitian Yogani dkk dimana kelompok yang tidak patuh memiliki rasio 3,268 kali tidak mengalami kenaikan CD4. ${ }^{(9)}$ Kerjasama yang baik antara tenaga kesehatan dan pasien serta komunikasi didukung dengan pengobatan yang konstruktif akan membantu pasien patuh dalam minum 
obat. ${ }^{(10)}$

Pada penelitian ini menunjukan bahwa terdapat perbedaan antara pasien yang bekerja dengan tidak bekerja terhadap CD4 sesudah pengunaan. Pasien yang bekerja cenderung mempunyai penghasilan lebih tinggi dibanding yang tidak bekerja sehingga dapat memenuhi kebutuhan hidup sehari-hari dan mempunyai kualitas hidup yang lebih baik dari pada yang tidak bekerja, selain itu walaupun pengobatan HIV disiapkan gratis oleh pemerintah, pasien membutuhkan uang untuk transportasi menuju tempat klinik yang ditunjuk pemerintah dalam pengobatan HIV, dengan adanya penghasilan dapat memudahan hal tersebut sehingga berdampak baik pada keberhasilan penggunaan obat ARV. Hal ini dibenarkan oleh studi yang dilakukan oleh Kusuma tahun 2010, menyebutkan penghasilan keluarga tidak hanya kebutuhan sehari-hari akan tetapi terkait dengan biaya pengobatan dan perawatan sehingga hal ini dapat menjaga derajat kesehatan pasien secara keseluruhan. ${ }^{(11)}$

Pada penelitian ini menunjukan bahwa terdapat perbedaan bermakna antara status pendidikan pasien terhadap CD4 sesuah pengobatan. Pasien yang mempunyai tingkat pendidikan tinggi cenderung mempunyai pengetahuan yang lebih baik, demikian juga sebaliknya. ${ }^{(12)}$ Dengan adanya pengetahuan yang baik, pasien dapat memaksimalkan pengobatan HIV sehingga mempengaruhi kenaikan CD4. Tingkat pendidikan formal dapat meningkatkan daya nalar dan jalan untuk memudahkan seseorang untuk menerima motivasi dari lingkungan luar, dengan adanya motivasi dari luar akan menambah semangat seseorang untuk melakukan pengobatan sehingga dapat memaksimalkan keberhasilan penggunaan ARV.

Pada penelitian ini menunjukan bahwa tidak terdapat perbedaan bermakna antara usia terhadap CD4 sesudah pengobatan. Hal tersebut membuktikan bahwa usia bukan menjadi faktor dalam menghambat atau menaikan jumlah CD4, sejalan dengan penelitian di Puskesmas Gedongtengen Yogyakarta tahun 2018 yang menyatakan tidak adanya hubungan antara usia dengan status imunitas orang dengan HIV-AIDS (ODHA). ${ }^{(13)}$

Tidak adanya perbedaan bermakna juga didapatkan pada karakteristik jenis kelamin terhadap CD4 sesudah pengobatan. Hal tersebut bisa dikarenakan sebagian besar subjek penelitian adalah laki-laki. Hasil ini juga sejalan dengan penelitian Zulkarnain tahun 2018 yang menyatakan jenis kelamin tidak mempengaruhi status 
imunitas orang dengan HIV-AIDS. ${ }^{(13)}$

Infeksi Oportunistik (IO) dapat menyertai penderita HIV dikarenakan keadaan imun pasien menurun. Infeksi yang umum terjadi pada pasien HIV yaitu Kandidiasis, Virus sitomegalia (CMV), Virus herpes simpleks, Mycobacterium avium complex (MAC atau MAI). Subjek penelitian tidak terdapat gejala yang menunjukan adanya infeksi oportunistik dan komplikasi penyakit apapun, dan dengan penggunaan ARV dimana kita ketahui ARV digunakan untuk mengurangi kesakitan dan memperbaiki kualitas hidup pasien HIV sehingga sesudah penggunaan ARV tidak ditemukannya infeksi oportunistik tersebut. Menurut Mirna tahun 2015 ARV dapat memperbaiki sistem imun dalam tubuh sehingga mencegah terjadinya infeksi oportunistik. ${ }^{(14)}$ hal ini di dukung oleh Ditjen P2PL Kementerian Kesehatan tahun 2011 yang menyatakan penggunaan ARV memberikan harapan untuk dapat hidup secara normal, dapat memulihkan imunitas sehingga kuat untuk mengurangi kemungkinan terjadinya infeksi oportunistik, meningkatkan kualitas hidup, serta mengurangi kesakitan dan kematian terkait HIV. ${ }^{(5)}$

Jenis kombinasi obat juga menunjukan tidak adanya perbedaan bermakna terhadap CD4 sesudah pengobatan. Tidak ada hubungan ini menunjukkan bahwa semua kombinasi ARV efektif menaikkn CD4 pada pasien HIV. Hal ini sesuai dengan penelitian Yogani et. al tahun 2014 yang menyatakan jenis HAART yang diberikan tidak berhubungan dengan kenaikan CD4.

Pada penelitian ini didapatkan hasil kombinasi ARV yang paling banyak digunaakan dalam pengobatan HIV adalah TDF(300)+3TC(300)+EFV(600) dalam bentuk FDC (fixed-dose combination) dengan rata-rata peningkatan CD4 tertinggi yaitu 129 $\mathrm{sel} / \mathrm{mm}^{3}$. Hasil tersebut sejalan dengan penelitian Gabriella tahun 2017 pada pasien HIV dengan stadium 4 WHO didapatkan peningkatan rata-rata $352,571 \mathrm{sel} / \mathrm{mm}^{3}$ dengan pemberian kombinasi TDF+3TC+EFV selama 6 bulan. ${ }^{(15)}$

Kombinasi obat ARV yang digunakan pasien HIV mempunyai dampak baik dalam peningkatan CD4 pasien. Hal tersebut didukung dengan penelitian lain di RSUD DOK II Jayapura yang setelah 6-12 bulan pengobatan ARV diperoleh kenaikan limfosit $\mathrm{CD4}^{+}$rata-rata lebih dari $100 \mathrm{sel} / \mathrm{mm}^{3}$, sehingga dapat dikatakan pengobatan ARV memberikan respon imun yang baik pada pasien HIV/AIDS di RSUD DOK II Jayapura. ${ }^{(14)}$ 
Obat ARV golongan NRTI (nucleoside reverse transcriptase inhibitor) bekerja dengan menghambat reverse transcriptase sehingga perubahan RNA menjadi DNA terhambat, yang termasuk dalam golongan NRTI yang digunakan dalam penelitian ini adalah zidovudine (ZDV), lamivudine (3TC) dan tenovir (TDF). Obat ARV golongan NNRTI (nonnucleoside reverse transcriptase inhibitor) bekerja dengan berikatan langsung dengan reseptor pada reverse transcriptase, obat NNRTI yang diguanakn dalam penelitian ini adalah nevirapin (NVP) dan efavirenz (EFV). ${ }^{(5)}$

\section{Kesimpulan}

Pasien HIV di RS. Prof. Dr. Sulianti Saroso yang menggunakan ARV dalam 1 tahun pertama pengobatan sebagian besar mengalami perbedaan bermakna antara CD4 awal dan CD4 akhir. Bedasarkan peningkatan CD4 sesudah pengobatan, kombinasi TDF(300)+ $3 \mathrm{TC}(300)+E F V(600)$ adalah paling tinggi.

\section{Ucapan Terima Kasih}

Penulis mengucapkan terima kasih kepada institusi RS. Prof. Dr. Sulianti Saroso dan semua pihak yang terlibat dalam proses pengumpulan data.

\section{Daftar Pustaka}

1. Kementrian Kesehatan RI. Situasi dan Analisi HIV/AIDS. Pusat Data Dan Informaasi Kementeri Kesehatan RI. 2014;1-7.

2. Kementerian Kesehatan RI. Laporan Situasi Perkembangan HIV/AIDS dan PIMS di Indonesia Tahun 2018. Direktorat Jenderal Pengendali Penyakit dan Penyehatan Lingkungkungan [Internet]. 2018;1-30.

3. UNAIDS. UNAIDS Data 2019. 2019;1-388.

4. Kementerian Kesehatan RI. Peraturan Menteri Kesehatan RI No 87 Tahun 2014 tentang Pedoman Pengobatan Antiretrovial. Kementerian Kesehatan RI 2014 p. $1-122$.

5. Departemen Kesehatan RI. Pedoman Nasional Tatalaksana Klinis Infeksi HIV dan Terapi Antiretroviral. 2011. 1-108 p.

6. Larasaty N., Shaluliyah Z, Suryoputro A. Bentuk - bentuk dukungan keluarga terhadap ibu dengan HIV positif dalam kepatuhan Terapi ARV di kota Semarang. J Promosi Kesehat Indones Vol. 2015;10(2):116-30.

7. Audhah $\mathrm{MH}$, Agustina M. Hubungan Dukungan Emosional Keluarga dengan Keberhasilan Pelaksanaan Program Pengobatan HIV / AIDS di. 
Indones J Infect Dis. 2014;2:40-4.

8. Nasution RD. Identifikasi karakteristik orang risiko tinggi HIV dan AIDS tentang program pelayanan voluntary counseling and testing (VCT). 2015;3(2):54-67.

9. Yogani I, Karyadi TH, Uyainah A, Koesnoe S. Faktor-faktor yang Berhubungan dengan Kenaikan CD4 pada Pasien HIV yang Mendapat Highly Active Antiretroviral Therapy dalam 6 bulan Pertama. J Penyakit Dalam Indones. 2015;2(4):217.

10. Departemen Kesehatan RI. Pedoman Pelayanan Kefarmasian Untuk Orang Dengan HIV AIDS. In: Pedoman Pelayanan Kefarmasian untuk Orang dengan HIV/AIDS ODHA ). 2006. p. 1-74.

11. Kusman Ibrahim YKH. Hubungan antara Fatigue, Jumlah CD4, dan Kadar Hemoglobin pada Pasien yang Terinfeksi Human Immunodeficiency Virus (HIV).
Jurnal Keperawatan Padjadjaran. 2018;5(3):271-80.

12. Oktarina Hanafi F. Budisuari M.A. Hubungan Antara Karakteristik Responden, Keadaan Wilayah dengan Pengetahuan , Sikap Terhadap HIV/AIDS pada Masyarakat Indonesia.

13. Rope ZZ. Faktor-faktor yang mempengaruhi status imunitas ODHA di Puskesmas Gedongtengen Yogyakarta. 2018;1-12.

14. Mirna W, Sandy Semuel, Eva F. Dampak Perpaduan Obat ARV pada Pasien HIV / AIDS ditinjau dari Kenaikan Jumlah Limfosit CD4 + di RSUD Dok II Kota Jayapura. Plasma. 2015;1(2):53-8.

15. Gabriella Giovani. Perbandingan Kadar CD4 Sebelum Dan Sesudah ARV Minimal 6 Bulan Pada Pasien HIV di Puskesmas Bumiwonorejo Kabupaten Nabire. 2017;1-3. 